\title{
UPAYA MENINGKATKAN HASIL BELAJAR PESERTA DIDIK MELALUI MODEL PROBLEM BASED LEARNING DI MASA PANDEMI
}

\author{
Mayawati $^{1}$, Anggria Septiani Mulbasari ${ }^{2}$, Nurjannah ${ }^{3}$ \\ SMAN 1 Bunguran Timur Kabupaten Natuna Kepulauan Riau ${ }^{1}$ \\ Universitas PGRI Palembang ${ }^{2}$ \\ SMP Negeri 1 Palembang ${ }^{3}$ \\ mayawati@gmail.com ${ }^{1}$
}

\begin{abstract}
ABSTRAK
Kehadiran Covid-19 sangat mempengaruhi segala segi kehidupan hingga merambah ke dalam dunia pendidikan. Pola pembelajaran tatap muka dialihkan dengan memanfaatkan kecanggihan teknologi dengan belajar secara online. Ketidaksiapan sekolah dalam menghadapi perubahan yang mendadak, rendahnya penguasaan teknologi, keterbatasan sarana dan prasarana hingga jaringan internet, serta besaran biaya yang harus diperhitungkan merupakan beberapa faktor yang menghambat terlaksananya efektivitas pembelajaran secara daring. Tujuan penelitian ini untuk mengetahui peningkatan hasil belajar peserta didik dan kemampuan guru dalam mengelola pembelajaran secara daring pada pembelajaran matematika menggunakan model Problem Based Learning. Penelitian dilaksanakan pada bulan Oktober 2020. Penelitian dilakukan dengan menerapkan metode Penelitian Tindakan Kelas yang meliputi perencanaan (planning), tindakan (acting), pengamatan (observing), dan refleksi (reflecting). Penelitian ini terdiri atas 2 siklus. Data dikumpulkan melalui observasi, tes, dan angket. Hasil penelitian ini adalah penerapan model Problem Based Learning (PBL) dapat meningkatkan hasil belajar peserta didik kelas XI MIPA 2 SMAN 1 Bunguran Timur pada materi matriks meski dilaksanakan secara virtual memanfaatkan whatsapp dan zoom. Peserta didik tampak antusias dalam menerima segala pola pembelajaran yang dilakukan. Meski di awal sempat sulit dikoordinasikan, namun seiring waktu semakin mampu untuk beradaptasi. Penyusunan perangkat dan ketepatan dalam mengalokasikan waktu, menjadi kunci dalam keberhasilan sebuah pembelajaran, apapun model pembelajaran yang digunakan.
\end{abstract}

Kata kunci : pandemi, berbasis masalah, hasil belajar

\begin{abstract}
The presence of Covid-19 has greatly affected all aspects of life to penetrate the world of education. Face-to-face learning patterns are transferred by taking advantage of technological sophistication by learning online. The unpreparedness of schools in facing sudden changes, low mastery of technology, limited facilities and infrastructure to the internet network, and the number of costs that must be calculated are some of the factors that hinder the implementation of effective online learning. The purpose of this study was to determine the improvement of student learning outcomes and the ability of teachers to manage online learning in mathematics learning using the Problem Based Learning model. The research was conducted in October 2020. The study was conducted by applying the Classroom Action Research method which
\end{abstract}


includes planning, acting, observing, and reflecting. This study consisted of 2 cycles. Data were collected through observation, tests, and questionnaires. The results of this study are the application of the Problem Based Learning (PBL) model can improve the learning outcomes of class XI MIPA 2 SMAN 1 Bunguran Timur on the matrix material even though it is implemented virtually using WhatsApp and zoom. Students seem enthusiastic about accepting all the learning patterns carried out. Even though at the beginning it was difficult to coordinate, but over time they were more able to adapt. Arrangement of tools and accuracy in allocating time are the keys to the success of learning, regardless of the learning model used.

Keywords : pandemic, problem based, learning outcomes

\section{PENDAHULUAN}

Keadaan dunia saat ini sedang mengalami krisis berat di bidang kesehatan. Kehadiran Covid-19 sangat mempengaruhi segala segi kehidupan hingga merambah ke dalam dunia pendidikan. Virus yang disinyalir mulai mewabah 31 Desember 2019 di Kota Wuhan Provinsi Hubei Tiongkok, menyebar hampir ke seluruh penjuru dunia dengan sangat cepat, sehingga WHO menetapkan wabah ini sebagai pandemi global (Elmunsyah, dkk, 2020). Bahkan pada Rabu 5 Maret 2020, UNESCO menyatakan bahwa hampir 300 juta peserta didik di seluruh dunia merasakan dampak yang sama (Handoyo, 2020). Pola pembelajaran tatap muka dialihkan dengan memanfaatkan kecanggihan teknologi, belajar dalam jaringan (daring) dengan memanfaatkan aplikasi pembelajaran online.

Ketidaksiapan sekolah dalam menghadapi perubahan pola pembelajaran, rendahnya penguasaan teknologi, keterbatasan sarana dan prasarana hingga jaringan internet, serta besaran biaya yang harus diperhitungkan merupakan beberapa faktor yang menghambat terlaksananya efektivitas pembelajaran secara daring. Namun, perubahan paradigma tentang pelaksanaan proses belajar-mengajar harus siap dilakukan oleh seluruh stakeholder pendidikan yang terdiri dari orang tua, guru, sekolah, hingga pemerintah.

Situasi saat ini merupakan tantangan bagi dunia pendidikan, mengubah manajemen pengelolaan pendidikan sangat diperlukan untuk mengimbangi perubahan yang sangat cepat. Metode pembelajaran manual dan konvensional saat ini mulai tergantikan dengan sistem digital daring (dalam jaringan) tanpa dibatasi ruang dan waktu. Secara proses, sebenarnya model pembelajaran modern ini sudah diatur dalam Permendikbud No. 22 Tahun 2016 tentang standar proses dengan prinsip, dari peserta didik diberitahu menuju peserta didik mencari tahu. Dari guru sebagai satu-satunya sumber belajar menjadi belajar berbasis aneka sumber belajar. Dari pendekatan tekstual menuju proses sebagai penguatan penggunaan pendekatan ilmiah. Dari pembelajaran parsial menuju pembelajaran terpadu. Dari pembelajaran yang menekankan jawaban tunggal menuju pembelajaran dengan jawaban yang kebenarannya multidimensi. Dari pembelajaran verbalisme menuju keterampilan aplikatif. Peningkatan dan keseimbangan antara keterampilan fisikal (hardskills) dan keterampilan mental (softskills). 
Dalam pembelajaran matematika, keterampilan menghitung, kemampuan memecahkan masalah, dan berpikir kritis adalah komponen penting dalam mengukur keberhasilan. Namun, melakukan pembelajaran matematika di masa pendemi ini menjadi sebuah tantangan tersendiri. Dibutuhkan berbagai strategi untuk meningkatkan aktivitas yang memacu minat belajar anak serta akan berdampak pada peningkatan hasil belajar.

Peranan matematika sangat penting dalam menunjang pembangunan di bidang pendidikan karena matematika merupakan penunjang ilmu pengetahuan lainnya dan pendukung bagi kemajuan teknologi. Simanjuntak (1993:64) mengatakan bahwa "Jatuh bangunnya suatu negara dewasa ini sangat bergantung dari kemajuan di bidang matematikanya".

Salah satu materi yang dipelajari dalam matematika, yaitu matriks. Matriks merupakan bagian dari aljabar. Sekilas materi ini terlihat mudah, namun pada aplikasinya dalam kehidupan, matriks tidak cukup dipandang sebelah mata. Nyatanya, tidak semua peserta didik bisa menerima pembelajaran ini dengan baik. Hal ini dapat terlihat dari hasil belajar yang diperoleh. Sudah menjadi sesuatu yang lumrah dalam belajar matematika, semakin di akhir level sub materi yang dipelajari akan semakin tinggi. Maka, titik fokus dan semangat anak dalam belajar akan mengalami penurunan secara otomatis. Disinilah dibutuhkan kompetensi guru.

Sebelum mempelajari materi matriks, peserta didik sudah terlebih dahulu mempelajari materi Program Linier. Pada kondisi tatap muka, materi ini juga bisa diterima dengan baik oleh peserta didik, terutama kelas MIPA. Hal ini dibuktikan dengan data hasil belajar 2 tahun terakhir. Kemampuan belajar mengalami ketuntasan. Namun, pada awal adaptasi pembelajaran daring dengan materi yang sama, ketuntasan belajar mengalami penurunan. Padahal, kelas yang akan dijadikan subjek penelitian merupakan salah satu kelas unggulan di SMAN 1 Bunguran Timur. Faktor yang mendominasi terjadinya penurunan tersebut, antara lain:

1) Dari Segi Guru. Guru belum menguasai teknik pembelajaran yang akan dilakukan. Di awal kegiatan, terjadi beberapa perubahan jadwal. Dalam satu kali pertemuan, guru juga harus melakukan pembelajaran terhadap beberapa kelas sekaligus. Perubahan pola pembelajaran yang akan dilakukan, menjadi sebuah tantangan bagi guru dan membutuhkan waktu untuk bisa beradaptasi dengan baik. Sehingga pada awal pelaksanaan, banyak bagian dari KBM yang tidak terlaksana secara maksimal, maka berimbas pada aktivitas dan hasil belajar.

2) Dari Segi Peserta Didik. Adaptasi pembelajaran baru mempengaruhi semua bagian dari pelaku kegiatan pembelajaran. Kurangnya motivasi dan semangat dapat terlihat dari pertemuan yang dilakukan dengan memuat unsur-unsur TPACK. Alasan utama adalah kesulitan signal dan kuota. Anak juga lebih sulit dikoordinasikan dan tidak terlihat interaksi aktif secara menyeluruh. Peserta didik yang mau belajar secara daring adalah orang yang sama dan terbiasa aktif dalam pembelajaran tatap muka. Peserta didik yang cenderung pasif dan lemah dalam menerima pembelajaran, semakin mengalami penurunan dalam Pembelajaran Jarak Jauh (PJJ). Untuk tugas yang diberikan, beberapa anak cenderung lalai. Karakter kejujuran juga memberikan tanda tanya besar karena peluang dalam melakukan kecurangan lebih dominan untuk dilakukan. 
Menurut Najeela Shihab dalam webinar Pemanfaatan Internet sebagai Media Penyebaran Informasi dalam Upaya Melindungi Diri dari Bahaya Pandemi Covid -19 yang disiarkan langsung melalui kanal youtube Bakti Kominfo (03/05/2020), dikatakan bahwa tiga kompetensi utama pendidikan harus tetap diberikan meski pembelajaran dilakukan secara daring yaitu kemampuan guru dalam membimbing peserta didik agar dapat merdeka dalam belajar, merdeka berkolaborasi, dan merdeka dalam berkarya (Agustini, 2020).

Kemerdekaan ini yang masih belum bisa terlaksana secara optimal dan menjadi tantangan terbesar bagi dunia pendidikan. Beberapa orang tua khawatir akan terjadi pembodohan massal bagi pola pembelajaran yang keliru. Dalam pembelajaran secara tatap muka, diperlukan berbagai trik khusus agar pembelajaran matematika terasa menyenangkan dan mudah untuk diterima. Apalagi pembelajaran yang dilakukan secara daring, diperlukan kreativitas dan inovasi guru dalam mengelola kelas dan konsep pembelajaran, agar "Ratu Ilmu" yang bernama matematika bisa diterima dan mendapatkan hasil belajar yang optimal.

Setelah beberapa bulan beradaptasi dengan pola yang baru, diharapkan pada pelaksanaan pembelajaran menggunakan materi ini tidak menurunkan hasil belajar peserta didik. Berdasarkan uraian latar belakang di atas maka dilakukan penelitian yang bertujuan untuk meningkatkan hasil belajar materi Matriks siswa kelas XI MIPA 2 SMAN 1 Bunguran Timur melalui penerapan model pembelajaran Problem Based Learning di masa Pandemi.

\section{METODE}

Penelitian ini merupakan Penelitian Tindakan Kelas (PTK) yang mengkaji masalah pembelajaran di kelas melalui proses refleksi diri dengan melakukan berbagai tindakan yang terencana dalam situasi nyata serta menganalisis setiap pengaruh dari tindakan yang dilakukan (Aqib, 2009).

Penelitian dilakukan dengan menerapkan metode Penelitian Tindakan Kelas model Kurt Lewin (Kusumah dan Dwitagama, 2012) yang meliputi empat komponen, yaitu perencanaan (planning), tindakan (acting), pengamatan (observing), dan refleksi (reflecting). Keempat komponen ini membentuk satu siklus. Penelitian ini terdiri dari 2 siklus. Subjek penelitian ini adalah peserta didik kelas XI MIPA 2 SMAN 1 Bunguran Timur yang berjumlah 27 dengan karakteristik heterogen, terdiri dari 6 orang laki-laki dan 21 orang perempuan. Teknik pengumpulan data yang digunakan terdiri dari observasi, tes, catatan lapangan dan dokumentasi.

Data kuantitatif peserta didik akan dianalisis secara deskriptif untuk mengetahui kualitas hasil belajar. Peningkatan hasil belajar peserta didik dapat diketahui dengan cara membandingkan skor individu dengan skor kelompok, yang diperoleh sebelum dan sesudah mengikuti pelajaran. Data hasil belajar didapat melalui hasil tes. Pada setiap siklus dilakukan satu kali evaluasi. Skor maksimal yang diperoleh peserta didik adalah 100, sedangkan skor rata-rata tes peserta didik dapat dihitung dengan rumus:

$$
\bar{x}=\frac{\sum x}{N}
$$


Keterangan:

$\bar{x} \quad$ : nilai rata-rata

$\sum x$ : Jumlah skor keseluruhan

$N$ : Jumlah peserta didik

Kriteria Ketuntasan Minimal (KKM) kelas XI MIPA 2 SMAN 1 Bunguran Timur adalah 78,00, maka standar ketuntasan individu dan standar ketuntasan klasikal akan diinterpretasikan sebagai berikut:

1. Standar Ketuntasan Individu

Secara perorangan dianggap telah "tuntas belajar" jika daya serap peserta didik mencapai 78,00.

2. Standar Ketuntasan Klasikal

Secara klasikal, dianggap telah "tuntas belajar" jika mencapai $80 \%$ dari jumlah peserta didik yang mencapai daya serap minimal 78. Sedangkan untuk mengetahui ketuntasan belajar (KB) secara klasikal menggunakan rumus sebagai berikut:

$$
K B=\frac{n}{N} x 100 \%
$$

Keterangan:

$K B:$ Ketuntasan Belajar

$n$ : Banyak peserta didik yang mencapai nilai di atas 78

$N$ : Banyak peserta didik yang mengikuti tes

Selanjutnya ditentukan tingkat penguasaan peserta didik terhadap materi, untuk menentukan golongan tingkat penguasaan peserta didik, digunakan klasifikasi penelitian sebagaimana yang dikemukakan oleh Sudijono (2001) yang ditunjukkan pada tabel 1 berikut:

Tabel 1. Klasifikasi penilaian

\begin{tabular}{cc}
\hline Angka & Kriteria \\
\hline $30-39$ & Gagal \\
$40-55$ & Kurang \\
$56-65$ & Cukup \\
$66-79$ & Baik \\
$80-100$ & Baik sekali \\
\hline
\end{tabular}

\section{HASIL DAN PEMBAHASAN}

Penelitian Tindakan Kelas ini dilaksanakan di kelas XI MIPA 2 SMAN 1 Bunguran Timur Kecamatan Bunguran Timur Kabupaten Natuna Provinsi Kepulauan Riau. Penelitian dilakukan dalam 2 siklus untuk menentukan hasil belajar peserta didik melalui model pembelajaran Problem Based Learning (PBL) pada materi matriks selama masa pandemi dengan menggunakan pola pembelajaran jarak jauh. Berdasarkan penelitian yang dilaksanakan, mulai dari pemeriksaan tahap studi awal hingga sampai pada siklus II, diperoleh data sebagai berikut: 


\section{Deskripsi Tahap Studi Awal}

Data yang diperoleh dari observasi hasil belajar peserta didik kelas XI MIPA 2 sejak kelas $\mathrm{X}$ hingga sekarang selalu menunjukkan hasil yang bagus. Mereka termasuk kategori anak yang mau belajar dan berkembang. Hanya beberapa siswa yang terlihat pasif namun bisa tertutupi dengan semangat belajar dari peserta didik yang aktif. Untuk materi matriks sejak 2 tahun terakhir dengan kelas yang berbeda menunjukkan bahwa ketuntasan hasil belajar selalu memuaskan. Dari beberapa tanya jawab yang dilakukan dengan beberapa peserta didik dari angkatan sebelumnya, mayoritas memberikan jawaban bahwa matriks termasuk materi yang mudah dan menyenangkan. Namun, dicoba untuk mengetahui kemampuan belajar dari kelas subjek sekaligus hasil belajar yang akan diperoleh dari materi matriks ini ketika dilakukan secara online dengan menerapkan pembelajaran Problem Based Learning (PBL).

Pada pertemuan awal sebelum pelaksanaan kegiatan dilaksanakan tanggal 14 Oktober 2020 tampak beberapa anak mengalami kebingungan dengan pola pembelajaran yang dilaksanakan. Beberapa anak masih sulit untuk dikoordinasikan dan beradaptasi dengan pembelajaran menggunakan zoom. Bahkan ada beberapa peserta didik yang kesulitan untuk bergabung akibat keterbatasan sinyal.

\section{Deskripsi Hasil Penelitian Siklus I}

Kegiatan siklus I ini dilaksanakan dalam 2 kali pertemuan dengan materi definisi matriks, jenis-jenis matriks, kesamaan dua matriks, dan transpose matriks.

Pertemuan 1

1) Perencanaan

Perencanaan tindakan ini merupakan tahap pertama yang dilakukan, dalam tahap perencanaan ini dilakukan tanya jawab dengan beberapa peserta didik angkatan sebelumnya tentang materi matriks yang sudah pernah dipelajari. Persiapan yang dilakukan antara lain menyusun rancangan RPP yang akan digunakan, mengidentifikasi standar kompetensi, menetapkan indikator, tujuan pembelajaran, menyiapkan bahan ajar, media pembelajaran yang akan digunakan, Lembar Kegiatan Peserta Didik (LKPD), lembar instrumen pengumpulan data, lembar evaluasi, lembar dokumentasi, serta sarana dan prasarana yang digunakan dalam pembelajaran siklus I.

2) Tindakan

Tahap berikutnya pengimplementasian dari perencanaan tindakan siklus I, pertemuan pertama pada tanggal 17 Oktober 2020. Selama pembelajaran jarak jauh dilakukan, alokasi waktu untuk satu kali pertemuan mengalami pengurangan 20 menit. Agar segala aktifitas yang sudah dirancang bisa dilaksanakan secara maksimal, maka beberapa menit sebelum pembelajaran dimulai, semua media pendukung, absensi, dan kelompok belajar sudah diserahkan terlebih dahulu melalui grup WhatsApp (WA) kelas. Bahan ajar digunakan sebagai pembuka kegiatan literasi. Selanjutnya, pembelajaran akan dilanjutkan melalui zoom sebagai pengganti tatap muka.

Pada kegiatan pembuka dengan menggunakan zoom, guru mengucapkan salam dan meminta salah seorang perwakilan kelas untuk memimpin doa. Guru juga menginformasikan hasil dari absensi yang sudah dilakukan, memberikan motivasi dan mengingatkan peserta didik untuk senantiasa mematuhi semua protokol kesehatan. Selanjutnya, guru menjelaskan tujuan dari pembelajaran yang 
akan dilakukan serta penjelasan tentang model pembelajaran yang akan digunakan. Dalam bagian apersepsi, guru menjelaskan tentang materi yang akan dipelajari dan kaitannya dengan beberapa materi sebelumnya. Guru melakukan tanya jawab secara singkat, peserta didik diberi kesempatan untuk menjawab dan guru memberikan penguatan.

Pada kegiatan inti, guru menampilkan bahan ajar dan menjelaskan sebagian dari gambaran materi yang akan dipelajari. Setelah penjelasan selesai diberikan, guru melakukan tanya jawab untuk menguji pemahaman peserta didik. Sub materi yang akan dipelajari pada pertemuan ini adalah Definisi Matriks. Diharapkan peserta didik dapat menyebutkan pengertian dan ordo matriks. Setelah memastikan bahwa mereka telah memahami materi, anak diberikan LKPD dan guru meminta mereka untuk bergabung ke dalam kelompok kooperatif yang sudah diberikan. Setiap kelompok diminta untuk melakukan diskusi aktif melalui kelompok WA masing-masing atau langsung melalui zoom. Guru melakukan koordinasi menyeluruh meski secara virtual. LKPD diselesaikan selama 20 menit.

Setelah LKPD selesai dikerjakan, guru meminta setiap kelompok untuk menampilkan hasil diskusi masing-masing. Kelompok yang akan tampil dipilih secara acak. Kelompok yang belum mendapatkan giliran, diminta untuk menyimak pemaparan dari kelompok penyaji dan melakukan tanya jawab. Guru memberikan apresiasi untuk setiap penampilan kelompok. Pembelajaran ditutup dengan memberikan evaluasi.

Pada kegiatan penutup, guru mengajak semua peserta didik untuk melakukan rangkuman/kesimpulan dari materi yang sudah dipelajari. Guru memberikan penghargaan kepada semua peserta didik atas partisipasi aktifnya. Guru memberikan pesan moral dan meminta mereka untuk mampu beradaptasi terhadap pola pembelajaran dan kehidupan di masa new normal. Tak lupa, guru mengingatkan materi selanjutnya dan menutup pembelajaran dengan doa bersama.

3) Pengamatan

Pada kegiatan siklus I pertemuan 1 yang dilakukan terlihat bahwa peserta didik tidak menggunakan seragam sekolah sebagaimana mestinya. Pembelajaran lebih terpusat pada guru, diskusi kelompok belum berjalan secara maksimal, belum terlihat interaksi aktif antara guru dan peserta didik. Guru tidak menegur peseta didik yang mematikan kamera tanpa izin pada saat proses pembelajaran berlangsung. Guru juga tidak bertanya tentang kesan yang dirasakan peserta didik saat melakukan pola pembelajaran ini. Pada saat proses evaluasi, kejujuran setiap peserta tidak bisa terukur. Beberapa peserta didik bahkan lalai dalam mengumpulkan lembar evaluasi yang sudah selesai dikerjakan. Sehingga bisa dikatakan bahwa kegiatan pembelajaran menggunakan model pembelajaran PBL belum terlaksana secara optimal pada pertemuan 1 siklus I ini.

4) Refleksi

Setelah pembelajaran selesai, guru melakukan proses refleksi terhadap kegiatan pembelajaran yang sudah berjalan. Refleksi dilakukan dengan memanfaatkan hasil rekaman selama pembelajaran berlangsung. Guru juga melakukan diskusi dengan dosen dan guru pamong, kemudian melakukan revisi sesuai masukan dan saran yang diberikan. Bentuk-bentuk refleksi yang akan dilakukan antara lain meminta semua peserta didik untuk menggunakan seragam sekolah meski pembelajaran dilakukan secara online. Langkah-langkah kegiatan 
pembelajaran dengan menerapkan model pembelajaran berbasis masalah harus lebih ditampakkan terutama saat peserta didik melakukan diskusi. Saat pembelajaran berlangsung, interaksi antar guru dan peserta didik harus lebih ditingkatkan dan tidak terpusat menyeluruh kepada guru. Peserta didik harus aktif dalam menemukan dan menyelesaikan masalah.

Pertemuan 2

1) Perencanaan

Pada tahap perencanaan pertemuan 2, guru masih tetap melakukan persiapan seperti pada pertemuan sebelumnya. Persiapan yang dilakukan antara lain menyusun rancangan RPP yang akan digunakan, mengidentifikasi standar kompetensi, menetapkan indikator, tujuan pembelajaran, menyiapkan bahan ajar, media pembelajaran yang akan digunakan, Lembar Kegiatan Peserta Didik (LKPD), lembar instrumen pengumpulan data, lembar evaluasi, lembar dokumentasi, serta sarana dan prasarana yang digunakan dalam pembelajaran siklus I.

2) Tindakan

Tahap berikutnya pengimplementasian dari perencanaan tindakan siklus I, pertemuan kedua dilakukan pada tanggal 19 Oktober 2020. Pada kegiatan pembuka dengan menggunakan zoom, guru mengucapkan salam dan meminta siswa berdoa. Guru juga menginformasikan hasil dari absensi yang sudah dilakukan, memberikan motivasi dan mengingatkan peserta didik untuk senantiasa mematuhi semua protokol kesehatan. Selanjutnya, guru menjelaskan tujuan dari pembelajaran yang akan dilakukan serta penjelasan tentang model pembelajaran yang akan digunakan. Dalam bagian apersepsi, guru menjelaskan tentang materi yang akan dipelajari dan kaitannya dengan beberapa materi sebelumnya. Guru melakukan tanya jawab secara singkat, peserta didik diberi kesempatan untuk menjawab dan guru memberikan penguatan.

Pada kegiatan inti, guru menampilkan bahan ajar dan menjelaskan sebagian dari gambaran materi yang akan dipelajari. Setelah penjelasan selesai diberikan, guru melakukan tanya jawab untuk menguji pemahaman peserta didik. Sub materi yang dipelajari pada pertemuan ini adalah Jenis-jenis dan Kesamaan Dua Matriks. Diharapkan peserta didik dapat menyebutkan 8 jenis matriks, mengetahui ciri khusus kesamaan dua matriks, dan bisa melakukan transpos matriks. Setelah memastikan bahwa mereka telah memahami materi, anak diberikan LKPD dan guru meminta mereka untuk bergabung ke dalam kelompok yang sudah diberikan. Setiap kelompok diminta untuk melakukan diskusi aktif melalui kelompok WA masing-masing atau langsung melalui zoom. Guru melakukan koordinasi menyeluruh meski secara virtual. LKPD diselesaikan selama 20 menit.

Setelah LKPD selesai dikerjakan, guru meminta setiap kelompok untuk menampilkan hasil diskusi masing-masing. Kelompok yang akan tampil dipilih secara random. Kelompok yang belum mendapatkan giliran, diminta untuk menyimak pemaparan dari kelompok penyaji dan melakukan tanya jawab. Guru memberikan apresiasi untuk setiap penampilan kelompok. Pembelajaran ditutup dengan memberikan evaluasi.

Pada kegiatan penutup, guru mengajak semua peserta didik untuk menyimpulkan dari materi yang sudah dipelajari. Guru memberikan penghargaan kepada semua peserta didik atas partisipasi aktifnya. Guru memberikan pesan moral dan meminta mereka untuk mampu beradaptasi terhadap pola pembelajaran 
dan kehidupan di masa new normal. Tak lupa, guru mengingatkan materi selanjutnya dan menutup pembelajaran dengan doa bersama.

3) Pengamatan

Pada pertemuan kedua, kegiatan pembelajaran secara virtual sudah jauh lebih baik. Guru dan peserta didik sudah mulai terbiasa dengan suasana ini. Interaksi antara guru dan peserta didik sudah lebih terlihat. Namun, beberapa peserta masih ada yang belum menggunakan seragam dan diskusi kelompok yang dilakukan masih kurang baik. Ada satu kelompok yang tidak bisa menampilkan hasil dan bukti diskusi. Beberapa peserta didik meminta izin tidak dapat mengikuti kegiatan karena cuaca sedang tidak mendukung.

4) Refleksi

Setelah kegiatan belajar-mengajar selesai, guru melakukan refleksi dengan menggunakan rekaman video dan hasil rangkuman saran dari dosen serta guru pamong. Bentuk refleksi yang akan dilakukan antara lain memastikan setiap peserta didik untuk kompak menjaga kerapian dengan menggunakan seragam yang sama. Masih ada beberapa bagian dari sintaks PBL yang tidak tampak secara dominan dan berusaha menyusun rancangan kegiatan yang lebih menarik dari sebelumnya. Guru harus bisa melakukan koordinasi secara menyeluruh meski dilakukan secara virtual. Dari hasil evaluasi juga belum mencapai hasil yang memuaskan. Beberapa peserta didik tidak tuntas karena beberapa faktor, seperti tidak meyimak dan mengikuti pembelajaran dengan baik, beberapa peserta didik absen dalam pelaksanaan, dan lalai saat mengumpulkan evaluasi.

\section{Temuan dari Hasil Penelitian Siklus I}

Berdasarkan penelitian yang telah dilakukan, diperoleh beberapa hasil temuan sebagai berikut:

a) Peserta didik terlihat lebih antusias dalam melakukan proses pembelajaran dengan menggunakan media yang menarik, LKPD yang inovatif dan variatif, serta model pembelajaran yang sistematis meski hanya secara virtual.

b) Ketika minat belajar anak terbangun, maka akan memberikan hasil belajar yang bagus.

c) Problem Based Learning menerapkan pembelajaran kooperatif, namun bisa terlaksana meski secara virtual jika menggunakan teknik yang sesuai, sistematis, dan berkesinambungan.

d) Sebagai guru abad 21, perlu menguasai pola pembelajaran yang berbeda dan disesuaikan dengan kemajuan zaman. Kecanggihan teknologi bisa dimanfaatkan asal mau belajar.

\section{Deskripsi Hasil Penelitian Siklus II}

Kegiatan siklus II ini dilaksanakan dalam 2 kali pertemuan dengan materi operasi penjumlahan dan pengurangan matriks.

Pertemuan 1 dan 2

1) Perencanaan

Persiapan yang dilakukan antara lain menyusun rancangan RPP yang akan digunakan, mengidentifikasi standar kompetensi, menetapkan indikator, tujuan pembelajaran, menyiapkan bahan ajar dan media pembelajaran, Lembar Kegiatan Peserta Didik (LKPD), lembar instrumen pengumpulan data, lembar evaluasi, lembar dokumentasi, serta sarana dan prasarana yang digunakan dalam pembelajaran siklus II. 
2) Tindakan

Tahap berikutnya pengimplementasian dari perencanaan tindakan siklus II, pertemuan pertama dan kedua dilakukan pada hari yang sama tanggal 23 Oktober 2020 selama 4 x 35 menit terhitung dari pukul 13.30 hingga 15.50.

Pada kegiatan pembuka dengan menggunakan zoom, guru mengucapkan salam dan meminta siswa berdoa. Guru juga menginformasikan hasil dari absensi yang sudah dilakukan, memberikan motivasi dan mengingatkan peserta didik untuk senantiasa mematuhi semua protokol kesehatan. Selanjutnya, guru menjelaskan tujuan dari pembelajaran serta mengulang penjelasan tentang model pembelajaran yang akan digunakan. Dalam bagian apersepsi, guru menjelaskan tentang materi yang akan dipelajari dan kaitannya dengan beberapa materi sebelumnya. Guru melakukan tanya jawab secara singkat, peserta didik diberi kesempatan untuk menjawab dan guru memberikan penguatan. Setelah memastikan semua peserta didik siap untuk belajar, guru masuk ke dalam kegiatan inti.

Pada kegiatan inti, guru menampilkan bahan ajar dan menjelaskan sebagian dari gambaran materi yang akan dipelajari. Setelah penjelasan selesai diberikan, guru melakukan tanya jawab untuk menguji pemahaman peserta didik. Sub materi yang dipelajari pada pertemuan ini adalah operasi penjumlahan dan pengurangan matriks. Setelah memastikan bahwa mereka telah memahami materi, anak diberikan LKPD dan guru meminta mereka untuk bergabung ke dalam kelompok yang sudah ditetapkan. Setiap kelompok diminta untuk melakukan diskusi aktif melalui kelompok WA masing-masing atau langsung melalui zoom. Guru melakukan koordinasi menyeluruh meski secara virtual. LKPD diselesaikan selama 30 menit.

Setelah LKPD selesai dikerjakan, guru meminta setiap kelompok untuk menampilkan hasil diskusi masing-masing. Kelompok yang akan tampil dipilih secara random. Kelompok yang belum mendapatkan giliran, diminta untuk menyimak pemaparan dari kelompok penyaji dan lakukan tanya jawab. Guru memberikan apresiasi untuk setiap penampilan kelompok. Pembelajaran ditutup dengan memberikan evaluasi.

Pada kegiatan penutup, guru mengajak semua peserta didik untuk melakukan rangkuman/kesimpulan dari materi yang sudah dipelajari. Guru memberikan penghargaan kepada semua peserta didik atas partisipasi aktifnya. Guru memberikan pesan moral dan meminta mereka untuk mampu beradaptasi terhadap pola pembelajaran dan kehidupan di masa new normal. Tak lupa, guru mengingatkan materi selanjutnya dan menutup pembelajaran dengan doa bersama.

3) Pengamatan

Pada kegiatan siklus II, pertemuan 1 dan 2 dilakukan sekaligus. Pada kegiatan kali ini terlihat bahwa semua peserta didik sudah menggunakan seragam sekolah sebagaimana mestinya. Pembelajaran tidak lagi terpusat pada guru, telah terjadi interaksi aktif dan diskusi kelompok sudah maksimal. Guru mengingatkan peseta didik untuk mengaktifkan kamera dan meminta izin jika tidak bisa melakukannya. Juga mematikan fitur suara (mute) selama guru menjelaskan. Guru bertanya tentang kesan yang dirasakan peserta didik saat melakukan pola pembelajaran ini. Pada saat proses evaluasi, peserta didik menyelesaikan tugas tepat waktu. Ada sanksi yang diberikan jika anak melakukan kelalaian. Sehingga 
bisa dikatakan bahwa kegiatan pembelajaran menggunakan model pembelajaran PBL sudah terlaksana dengan baik pada siklus II. Hal ini bisa terjadi karena waktu dan kondisi yang mendukung.

4) Refleksi

Setelah proses pembelajaran berlangsung, guru melakukan proses refleksi terhadap kegiatan pembelajaran yang sudah berjalan. Refleksi dilakukan dengan memanfaatkan hasil rekaman selama pembelajaran berlangsung. Guru juga melakukan diskusi dengan dosen dan guru pamong, kemudian melakukan revisi sesuai masukan dan saran yang diberikan. Dari hasil refleksi yang dilakukan, semua peserta didik sudah menggunakan seragam sekolah meski pembelajaran dilakukan secara online. Langkah-langkah kegiatan pembelajaran dengan menerapkan model pembelajaran berbasis masalah sudah lebih terlihat step by step. Pada saat melakukan diskusi, sudah terlihat kerjasama yang baik. Pembelajaran tidak lagi didominasi oleh guru, interaksi dua arah sudah mulai terlihat dan berjalan secara tertib. Guru juga sudah melakukan penguatan. Dari hasil evaluasi terlihat bahwa hasil belajar tetap baik dan rata-rata peserta didik tuntas dalam belajar meski materi terus mengalami kenaikan tingkat kesulitan. Baik secara luring maupun daring, tidak mempengaruhi hasil belajar setiap anak karena mayoritas mereka memang memiliki kemampuan kognitif yang baik.

\section{Paparan Data Hasil Belajar Siklus I}

Setelah melaksanakan model pembelajaran kooperatif Problem Based Learning (PBL), guru melakukan evaluasi pada setiap akhir pertemuan. Hasil akhir diperoleh dengan menjumlahkan hasil evaluasi pertemuan 1 dan pertemuan 2 kemudian dibagi 2. Diperoleh bahwa nilai rata-rata peserta didik sudah $\geq 70$ namun masih belum mencapai KKM sekolah yaitu 78. Masih ada peserta didik yang lalai dalam menyelesaikan evaluasi sehingga nilai yang diperoleh harus dibagi 2. Dua orang peserta didik tidak mengikuti pembelajaran, keduanya tanpa keterangan. Persentase peserta didik yang tuntas baru $66,67 \%$. Tuntas di sini berarti tuntas dalam melakukan semua proses kegiatan hingga pelaksanaan evaluasi tepat waktu. Karena keaktifan belajar masih rendah sehingga mempengaruhi hasil belajar, maka pembelajaran dilanjutkan ke siklus II.

\section{Paparan Data Hasil Belajar Siklus II}

Pembelajaran di siklus II masih menerapkan model pembelajaran Problem Based Learning (PBL) dengan 2 kali pertemuan. Namun untuk siklus II ini, pertemuan 1 dan 2 dilakukan sekaligus selama 4 x 35 menit. Kegiatan yang dilakukan jauh lebih baik dengan formasi yang lengkap. Hal ini disebabkan oleh alokasi waktu yang panjang selama pelaksanaan. Sehingga, setiap langkah yang disusun dapat terlaksana tanpa terburu-buru. Kegiatan jauh lebih santai, interaksi lebih terlihat, tanya jawab bisa dilakukan dan evaluasi yang dikerjakan bisa dikirim tepat waktu. Semua peserta didik bisa hadir dan mengikuti pembelajaran dengan baik. Pengambilan evaluasi dilakukan satu kali dengan memuat semua materi yang dipelajari pada akhir siklus. Hasil belajar peserta didik pada siklus II mengalami peningkatan yang signifikan yaitu 86,29. Rata-rata nilai peserta didik dari 72,22 di siklus I meningkat menjadi 86,29 pada siklus II. Hal ini disebabkan oleh partisipasi yang diberikan oleh semua peserta didik. Hanya 1 orang yang berhalangan hadir karena menghadiri acara keluarga. Jika keaktifan belajar bisa terlaksana maka akan berdampak pada peningkatan hasil belajar. 
Peningkatan hasil belajar peserta didik dapat digambarkan pada grafik di bawah ini:

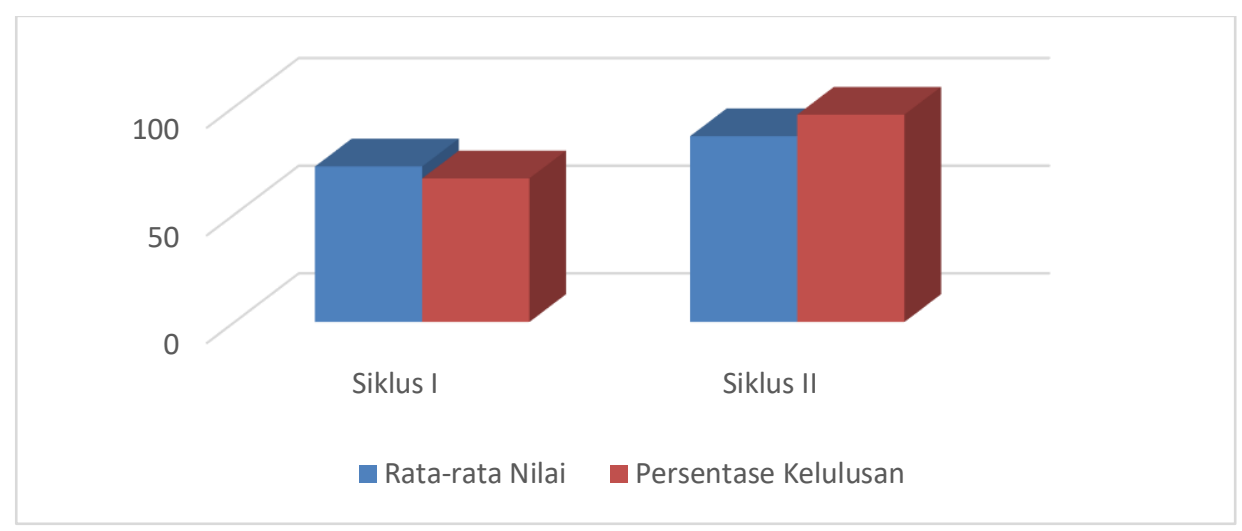

Grafik 1. Peningkatan nilai rata-rata dan persentase kelulusan peserta didik

Dengan demikian model pembelajaran berbasis masalah cukup tepat diterapkan karena membuat siswa aktif, sesuai dengan penelitian Firmansyah dkk (2020) bahwa Pembelajaran PBL lebih mengutamakan bagaimana siswa untuk menyelesaikan permasalahan dengan menggunakan pengetahuan yang dimilikinya dan pembelajaran PBL dapat mengembangkan pengalaman atas pengetahuannya dan kesadaran siswa terhadap berbagai masalah dalam kehidupan sehari-hari yang dialaminya serta dapat meningkatkan ketertarikan siswa terhadap matematika.

Dari penelitian Mulyani (2020) juga diperoleh hasil bahwa penerapan metode PBL dapat meningkatkan hasil belajar IPA di Kelas IV SD Negeri Karang Wuni 03 pada pembelajaran secara online di masa pandemi Covid 19. Terjadi peningkatan hasil belajar antara sebelum dan sesudah diterapkan metode pembelajaran Problem Based Learning yaitu sebesar 24,4 \% pada aspek kognitif, peningkatan nilai di aspek afektif sebesar $15 \%$, dan untuk aspek psikomotor terjadi peningkatan sebesar $15 \%$.

Pelaksanaan 'tindakan' dalam pembelajaran memang perlu selalu dilakukan. Melakukan tindakan berarti melakukan suatu perbuatan dalam lingkup pembelajaran yang bertujuan untuk memperbaiki proses pembelajaran dan hasilnya. Jangan sampai menunggu diadakannya Penelitian Tindakan Kelas dulu, baru dilakukan 'tindakan', tapi selalu kontinyu dilakukan dalam setiap proses pembelajaran. Dan pemberian 'tindakan' harus sesuai dengan permasalahan yang dihadapi, khususnya dalam masa pandemi ini.

\section{SIMPULAN DAN SARAN}

Model pembelajaran Problem Based Learning (PBL) dapat digunakan untuk meningkatkan hasil belajar peserta didik kelas XI MIPA 2 SMAN 1 Bunguran Timur pada materi matriks meski dilaksanakan secara virtual memanfaatkan whatsapp dan zoom. Peserta didik tampak antusias dalam menerima segala pola pembelajaran yang dilakukan. Meski di awal sempat sulit dikoordinasikan, namun seiring waktu semakin mampu untuk beradaptasi. Penyusunan perangkat, ketepatan dalam mengalokasikan waktu, dan pengelolaan suasana belajar menjadi kunci keberhasilan 
dalam sebuah pembelajaran, apapun model pembelajaran yang digunakan dan dalam setiap kondisi.

Disarankan kepada setiap pendidik, dalam melaksanakan pembelajaran daring, perlu mempersiapkan dan merancang semua perangkat pembelajaran secara tepat, agar proses pembelajaran berjalan dengan baik dan lancar.

\section{DAFTAR PUSTAKA}

Agustini, P. 2020. Tiga Kompetensi Utama Pendidikan Tetap Harus Dilakukan Saat Pandemi. Web Kominfo RI, 4 Mei 2020. [Online]. Tersedia : https://aptika.kominfo.go.id/2020/05/tiga-kompetensi-utama-pendidikan-tetapharus-dilakukan-saat-pandemi/

Aqib, Z., dkk. 2009. Penelitian Tindakan Kelas untuk Guru SD, SLB, dan TK. Bandung: CV. Yrama Widya.

Elmunsyah, H., Sutikno, T.A., Wibawa, A.P., dan Hidayat, W.N. 2020. Personalization Online Training System Berbasis Artificial Intelligence untuk Peningkatan Keterampilan Bagi Generasi Z Pada Era Pandemi Covid-19. [Online]. Tersedia : http://sinta.ristekbrin.go.id/covid/penelitian/detail/652.

Firmansyah, E., Mubarika, M.P., Taryudi, dan Ratnasari, S. 2020. Penggunaan Model Pembelajaran Problem Based Learning untuk Meningkatkan Kemampuan Pemecahan Masalah dan Motivasi Belajar Siswa. EDU-MAT: Jurnal Pendidikan Matematika, Vol. 8(1) : 62-73.

Handoyo. 2020. UNESCO: Wabah Virus Corona Ancam Pendidikan 300 Juta Siswa. Harian Kontan.co.id, 06 Maret 2020. [Online]. Tersedia : https://internasional.kontan.co.id/news/unesco-wabah-virus-corona-ancampendidikan-300-juta-siswa.

Kusumah, W. dan Dwitagama, D. 2012. Mengenal Penelitian Tindakan Kelas. Edisi Kedua. Jakarta: PT Indeks.

Mulyani, S. 2020. Penerapan Metode Pembelajaran Problem Based Learning Guna Meningkatkan Hasil Belajar IPA di Masa Pandemi Covid 19. Navigation Physics : Journal of Physics Education, Vol. 2(2) : 84-89.

Peraturan Menteri Pendidikan dan Kebudayaan Nomor 22 Tahun 2016 Tentang Standar Proses Pendidikan Dasar dan Menengah. [Online]. Tersedia : http://vervalsp.data.kemdikbud.go.id/prosespembelajaran/file/Permendikbud_T ahun2016_Nomor022_Lampiran.pdf

Simanjuntak. 1993. Pengertian Metode Pembelajaran. Jakarta: Pustaka Utama.

Sudijono, A. 2001. Pengantar Evaluasi Pendidikan. Jakarta: RajaGrafindo Persada. 